\title{
МАСОВНИ МЕДИЈИ, КУЛТУРНА ПОЛИТИКА И КУЛТУРНИ ОБРАЗАЦ У САВРЕМЕНОЈ СРБИЈИ
}

У раду се утврђује значај масовних медија као субјеката културне политике у савременом друштву. Полазећи од емпиријски утемељене чињенице да су они међу најзначајнијим друштвеним субјектима који утичи на културу у свакој социјалној заједници, проблематизује се питање њиховог функционисања у Србији. Наглашава се да масовни медији делују као субјекти културне политике изван друштвеним консензусом прихваћене и формално утврђене Стратегије развоја културе у нашој земљи. Осим непостојања такве стратегије, уочава се да се у важећем Закону о култури масовни медији уопште не спомињу као субјекти културне политике и, такође, да се у тзв. системским медијским законима културној акцији медијских организација придаје занемарљив значај. Последица је доминација културног обрасца који није у складу са социјално-историјским контекстом и развојним циљевима српског друштва. На крају су скицирани елементи културног образца, који треба да буде промовисан стартегијом развоја културе у Србији, као један од услова изласка земље из дубоке друштвене кризе, која је увек и криза културе.

Кључне речи: масовни медији, културна политика, стратегија развоја културе, доминантни културни образац, нови културни образац.

\section{Увод}

Комуникација и култура су две стране истог новчића који се зове људски живот. Преко њих он добија пуноћу, важност и сврху. Са њима хуманост добија смисао, а друштвени и лични односи значај. Култура даје животу место трајања, садржину и смисао бића, док му комуникација даје разлог постојања повезујући га са светом споља и изнутра, са временом и простором, са прецима и потомцима. (Jaнићијевић 2000: 9). 
На трагу ове, свакако темељне идеје професорке Јасне Јанићијевић о комуникацији и култури, изнетој у њеном истоименом делу, које ће дуго бити незаобилазно у промишљању човекове друштвене стварности, у овом раду биће проблематизована међузависност културне политике и деловања масовних медија у савременој Србији. У таквом проблемском оквиру рада методолошки се најпре намеће питање да ли су и у којој мери мас-медији, заправо медијске организације и запослени у њима, субјекти културне политике? Надаље, да ли у Србији постоји, утврђеним циљевима који су саобразни друштвено-историјском контексту, подједнако националном и глобалном, конзистентна стратегија развоја културе и из ње деривирана културна политика? И, најзад, јесу ли и на који начин медијске организације субјекти културне политике у српском друштву, као и које и какве културне политике?

Одговори на ова питања претпоставка су препознавања и критичког вредновања доминантног, као и скицирања пожељеног културног обрасца у савременом српском друштву.

\section{Масовни медији и култура}

Макар да прво од ових питања изгледа сувишно, јер је немогућ другачији до потврдан одговор, изнова се мора постављати, имајући у виду експлозиван развој и пролиферацију масовних медија на таласима текуће научно-технолошке револуције у последњих неколико деценија. Потпуна засићеност друштва масовним медијима на свим нивоима социјалног организовања и аритметичком прогресијом растућа присутност новог медија - интернета, у индивидуалном и друштвеном животу, води нас ка медијацентричном становишту да: „Медији више не врше само утицај на нашу културу. Они су наша култура" (Томан 2011). Ово, на први поглед, пренаглашено инсистирање на њиховом значају као демијурга културе утемељено је у бројним емпиријским истраживањима, укључујући и она релаизована код нас (види: Милетић 2009: 37-55), која показују растућу изложеност људи масовним медијима, до готово потпуне окупираности доколице медијским садржајима. Узимајући ту чињеницу у обзир, као и основне комуникационе функције масовних медија - информисање, 
забаву и образовање, оправдано је, барем, замислити се над поменутом тврдњом. У сваком случају, ако и није прихватљиво тврдити да су само медијски садржаји култура савременог човека, сигурно је да они представљају један од најважнијих, ако не и најважнији, аксиолошких оквира за разумевање савремене културе.

Поменуте комуникационе функције масовних медија, наиме, услов су остваривања њихових друштвених функција у просторној хоризонтали и временској вертикали. Кроз свакодневну културну акцију медији масовног комуницирања најдиректније утичу на формирање доминантног културног обрасца у друштву, који је симболички објективизиран у медијским садржајима кроз њихову непрестану ре-продукцију, а тиме и на степен интеграције одређеног друштва, његову унутрашњу равнотежу и стабилност, као и настајање и стварање нових културних вредности. Њиховим преношењем као културног наслеђа из епохе у епоху масовни медији, истовремено, омогућавају динамику колективног памћења, тиме и очување културног идентитета припадника одређене социјалне заједнице (детаљније у: Јанићијевић 2009: 198-213).

Утолико је истраживање и промишљање улоге масовних медија од прворазредног сазнајног значаја за разумевање културе у најопштијем смислу, али и у сваком посебном друштвеном систему, организованом у оквирима одређене национално-државне заједнице. То се посебено односи на разумевање институционализованих аспеката деловања масовних медија, тј. медијских организација које су у друштвеној подели рада специјализоване за прикупљање, селекцију, симболску обраду и дисеминацију различитих медијских садржаја, будући да су они носиоци мноштва информација и вредносних оријентација који обликују духовни, тиме културни живот појединаца, друштвених група и друштва у целини.

Стога је одговор на прво постављено питање недвосмилен: масовни медији, прецизније - медијске организације у оквиру којих функционишу, морају се третирати као изузетно значајни субјекти културне политике.Наравно, свака медијска организација укотвљена је у одређени друштвени контекст, који одговарајући израз налази у медијским садржајима. У том контексту постоји или не постоји конзистентна стратегија развоја културе и из ње деривирана културна политика. 


\section{Без стратегије развоја културе у Србији}

Узимајући претходне теоријске постулате у обзир, може се тврдити да без одговарајуће културне политике није могуће регулисати функционисање медијских организација као субјеката културне политике. Такође, да одређена културна политика може бити реализована само у оквиру јасне стратегије развоја културе у Србији. Али, управо ту је у нашој културној и медијској пракси чвориште проблема. Први његов аспект је у готово апсурдној чињеници да се у Закону о култури, донетом још 2009. Године („Службени гласник PC", бр. 72/2009), не само у делу који се односи на Стратегију развоја културе у Србији, него и у целини текста, медијске организације уопште не спомињу, а некмоли да се указује на њихов културни значај, односно друштвену улогу као субјеката културне политике.

Други аспект проблема изражен је непостојањем било какве стратегије културног развоја Србије, мада споменути закон у 19. и 20. члану имеперативно налаже њено утвриђивање за период од десет година. И даље, да Стратегија развоја културе треба да садржи: анализу постојећег стања културне делатности и стваралаштва у Србији, основне поставке културног развоја, стратешке правце и инструменте културног развоја, план реализације и критеријуме, индикаторе и поступке евалуације. Дакле - све елементе једне профилисане културне политике. Од доношења Закона о култури утврђивање Стратегије било је маргинално и вазда се појављивало само као најава, која никада није артикулисана одговарајућим документом. А словом овог закона држава је била у обавези да га донесе у року од годину дана од његовог ступања на снагу.

Томе насупрот, 2011. године Влада је утврдила Стратегију развоја система јавног информисања до 2016. године ${ }^{1}$ која, и таква каква је, ни у једном делу све до данас није реализована. Без имало малициозности - можда је и боље што се то није десило, јер и она не препознаје медијске организације као субјекте културне политике, спомињући културу само овлаш, у делу којим се дефинише јавни интерс, кроз опште напомене да се тај интерес

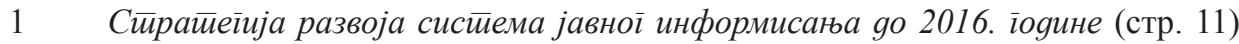
http://www.gs.gov.rs/lat/strategije-vs.html (приступљено 16. 3. 2014.). 
остварује „производњом и објављивањем (...) специјализованих медијских садржаја из (...) културе”, као и „медијских садржаја од значаја за очување културне баштине и медијских садржаја којима се промовише културно и уметничко стваралаштво и рад установа културе”. А далеко је од тога да је у њој упостављена било каква формална веза са (непостојећом) Стратегијом развоја културе у Србији. Из тога јасно проистиче да њени творци виде функционисање медијског система као од културе независног друштвеног подсистема.

Но, упркос фијаску који је ова стратегија доживела у пракси, од реализовања њених најважнијих циљева се не одустаје, на једној, нити се било шта чини у погледу утврђивања Стратегије културног развоја у Србији, на другој страни.

На прво указује кампања за доношење нових, тзв. медијских закона - Закона о јавном информисању и медијима, Закона о електронским медијима и Закона о јавним медијским сервисима, која траје и данас. ${ }^{2}$ Објављени текстови нацрта ових закона не уносе ни мало оптимизма о томе како ће медијске организације функционисати као субјекти културне политике. Њихов најмањи заједнички садржалац је апсолутизација либералистичког приступа медијском комплексу који се потпуно препушта тржишту, а то значи интерсним групама капитала, осима два РТВ организације (Србије и Војводине), које треба да буду у служби грађана, мада је мало вероватно да ће (досадашња пракса њиховог функционисања то показује) моћи да прескоче сопствену сенку политичке, односно страначке инструментализованости.

На друго указује потпуни изостанак Стратегије развоја културе у Србији из агенде најважнијих политичких субјеката, не само у текућем политичком животу, него и у тек завршеној предизборној кампањи (фебруар - март 2014). Гласови који се чују из делова културне јавности превише су слабашни да би се могла очекивати иоле

2 „Државна секретарка у Министарству културе и информисања Гордана Предић очекује да би медијски закони могли да се нађу пред Скупштином Србије до краја јуна. (...) Она је навела да је препорука из Брисела да се закони о јавном информисању, о јавним сервисима и о електронским медијима, усвоје најкасније до 1. октобра.” (http://www.blic.rs/Vesti/Drustvo/452794/Predic-Dokraja-juna-moguci-medijski-zakoni-u-parlamentu; приступљено 29. 3. 2014.) 
крупнија промена, тј. подизање културе на лествици друштвених приоритета до места које јој, иначе, припада. ${ }^{3}$

Дакле, одговор на друго питање постављено у уводном делу текста - да ли у Србији постоји, утврђеним циљевима који су саобразни друштвено-историјском контексту, подједнако националном и глобалном, конзистентна стратегија развоја културе и из ње деривирана културна политика - може да буде само негативан.

\section{Обриси доминантног културног обрасца Србији}

Али, без обзира на очигледну регулативну неусаглашеност развоја културе и функционисања масовних медија у Србији, медијске организације, чињеницом постојања и објављивања медијских садржаја, функционишу као један од најзначајнијих, ако не и најзначајнији субјекат културне политике. Директан израз је могућност препознавања одређеног доминантног културног обрасца у медијским садржајима који се, ослањањем на тврдњу Елизабет Томен (Elizabeth Thoman) са почетка текста, може препознати и као доминантни културни образац у савременом српском друштву. Њега карактерише некритичка глорификација неолибералне идеологије, која је у друштвеној пракси, довела до потпуне стагнације Србије у свим функционалним областима организовања друштва.

Уређивачке политике у медијским организацијама, као интегрални део културне политике, нису, највећим делом, утемељене у афирмисању аутентичних, националних и универзалних културних вредности, чијим би прихватањем српски народ и грађани Србије очували и модернизовали културно јасно профилисан национални иден-

3 Национални савет за културу изнео је резултате своје анализе стања у култури и своје мишљење о деловању Министарства: „Министарство није учинило ништа на плану Стратегије развоја културе у Републици Србији. Министарство је, одмах по ступању на дужност новог министра и новог државног секретара, обуставило рад на Стратегији и, мада је Савет у два наврата понудио Министарству помоћ у раду на Стратегији, током наредних шест месеци оно није ничим показало да је свесно значаја тог документа и није учинило ништа како би се рад на њему наставио.” (http://www.blic.rs/ Kultura/Vesti/447690/Nacionalni-savet-kritikuje-rad-Ministarstva-kulture; приступљено 29. 3. 2014.) 
титет, већ су у функцији тржишних императива и на њима заснованој дневној политици. Како указује Мелвин Дефлер (Дефлер 1966), циљ деловања масовних медија у сваком социјалном систему је обезбеђивање његове унутрашње равнотеже, која се постиже истовременим и усаглашеним деловањем медијског (произвођачи и дистрибутери медијских садржаја националног и локалног значаја), законодавно-политичког и економско-финансијског подсистема на масовну публику. Будући да се она стратификује на три нивоа укуса - висок (малобројни), просечан (бројни) и низак (најмногобројнији слој), и да се њени припадници, истовремено, појављују у улогама бирача и купаца, из угла равнотеже социјалног система прихватљиви су само они медијски садржаји који изазивају пажњу масовне публике, подстичу потрошаче да купују одређену робу и пружају подршку политичкој елити. Другим речима, да би се привукла пажња масовне публике, повећали тиражи новина, слушаност и гледаност радијских и телевизијских програма, а затим продала оглашивачима и предала политичкој елити, неопходно је повлађивати просечном и ниском укусу. Овакво деловање масовних медија у друштву изражава се у пракси масовног комуницирања кроз пораст сензационализма, доминацију таблоида у штампи, радијске и телевизијске програме у тзв. инфозабавном и инфокомерцијалном формату. Конзистентност у њима постоји у понуди медијских садржаја који грађанима, припадницима масовне публике, нуди могућност избора из „мноштва истог”. Та конзистентност је све опаснија, ако се имају у виду масовни медији са највећим тиражима, слушаношћу и гледаношћу у Србији, а посебно они који су основани да буду јавна служба или дуготрајношћу то јесу, независно од чињенице да ли су у јавном, мешовитом или приватном власништву.

Последица је настајање хибридног, тржишно условљеног доминантног културног обрасца у Србији, у којем се запостављају, често и омаловажавају, вековима стваране и, утолико, непорециве духовне вредности, односно значај њиховог очувања и усаглашавања са културним вредностима које настају као последица глобалних друштвених промена, изазваних текућом научно-технолошком револуцијом. Овај културни образац - као „мање или више конзистентан образац мишљења и деловања” (Бенедикт, 1976), односно „смисаони оквир оријентације и интеграције једне заједнице који обухвата, пре свега, 
вредносне системе помоћу којих појединци и друштвене групе долазе до разумевања себе и света у коме живе, као и моделе за акцију ради остваривања изабраних циљева и промовисања пожељног начина живота" (Голубовић, 1994: 35) - изражава се у Србији кроз неколико његових специфичних манифестација, својеврсних подобразаца унутар различитих друштвених сегмената, детерминисаних, првенствено, урбаним, периферијским или руралним социјалним амбијентом у којем се поменути доминантни образац остварује.

Мондијалистичка варијација доминантног културног обрасца последица је некритичког опонашања глобалних културних парадигми, њиховим локализовањем у урбаном друштвеном миљеу и стереотипном афирмацијом идеолошке мантре да Србија „мора постати Свет”, преузимањем културних образаца који су својствени тзв. развијеним демократским друштвима. Наглашено је политизована и подразумева начин мишљења који је увек и нужно у супротности са сваком културном вредношћу која има национални предзнак; карактерише је игнорисање националних вредности у пољу језика и писма, религије, митологије, традиције, обичаја, морала и уметности; као и агресивна потреба да се у овим културним вредностима траже (и налазе) узроци политичких и друштвених криза у прошлости и заостајању Србије у савремености. На културном плану израста из некритичке отворености према свему што долази из „развијеног света”, од политичких модела организовања друштва до тзв. културних производа, који су, баш због земаља настајања, „културне вредности по себи”. У пољу културне акције најбоље се може илустровати опредељењем „за Егзит”, а не „за Гучу”, иако је, како ће скицирањем естрадне варијације доминантног културног обрасца бити показано, и данашња „Гуча” део истог доминантног културног обрасца. Овде је прилика да се једним примером медијског, као културног деловања укаже на значај медијских организација у профилисању доминантног културног обрасца. Један од најучесталијих слогана којима у сопственом програму РТС свакодневно промовише себе и своју друштвену улогу је: „РТС - медијски јавни сервис евройске (подвукао аутор) Србије”. Семантичком анализом овог слогана лако је доћи до закључка да је искоришћена класична техника медијске манипулације, тзв. реч-замка (Бретон, 2000), којом се гледаоцима намеће једна политичка, дакле 
и културна оријентација. Наиме, овај слоган може се читати на два начина - дословно (денотативно значење) и интенционално (конотативно значење). Када се чита на први начин, слоган је готово бесмислен, јер сваки ученик четвртог разреда основне школе зна да је Србија (у географском смислу) европска земља. Такав слоган, онда има врдност исказа - „Сутра је нови дан”. Међутим, у овом слогану важно је у речи-замци (придеву „европска”) скривена интенција - његово конотативно значење да, зато што „Европа нема алтернативу”, међународна оријентација Србије мора бити чланство у Европској унији. Нека остане по страни што овакав слоган представља један од емпиријских доказа да РТС никада, суштински, није постао јавна служба свих грађана Србије, будући да међу њима, осим „еврофанатика” и „евроентузијаста”, такође има „еврореалиста”, „евроскептика” и „,антиевропејаца", којима РТС, такође, припада, јер и они из сопственог џепа плаћају функционисање ,јавног сервиса". Пример је наведен да се покаже и докаже значај медијских организација у формирању доминантног културног обрасца у Србији.

Спектакуларна манифестација овог обрасца егзистира у периферијско-провинцијалном друштвеном миљеу и такође је, у великој мери, медијски условљена. У општем сиромаштву, беспослици и безнадежности, који карактеришу свакодневни живот у Србији, грађани се, заморени драматичним збивањима током последњих деценија, идентификују са јунацима ријалити-шоу телевизијских програма, тзв. телевизијских-сапуница и естрадним личностима које пуне, не само класичне таблоиде, него су увелико постали део садржаја информативно-политичких дневних и периодичних новина. „Спектакл је новац који може да се гледа, јер је у њему сва употребна вредност већ размењена за тоталитет апстрактних представа. Спектакл није само слуга лажне корисности, већ је и сам лажна употреба живота.” (Дебор 1999: 7) Не треба, наиме, сметнути с ума да је први овакав телевизијски формат емитовала ТВ Б92 („Велики брат”) и поставила путоказ за забавне програме свих осталих комерцијалних телевизија. Овакви телевизијски и садржаји осталих масовних медија намењени су медијској наркотизацији танког средњег слоја и, већински, пауперизованог становништва Србије, у којој „више од 90\% становника живи у културном сиромаштву које већ прелази у духовну беду” (Митро- 
вић 2007) и којем се свакодневно нуди - минимум народног хлеба и обиље телевизијских игара. Најочајнији међу незапосленим људима и оним без редовних примања већ продају органе сопственог тела да би исхранили породице, а продаја приватности и интиме постала је неупитни културни стандард, које масовни медији експлатишу на најбизарније и највулгарније начине. Од „Фарме” и „Тренутка истине” до најтривијалнијих детаља из приватног живота јавних (и богатих) личности у, по броју преовлађујућим, таблоидима на тржишту дневне и периодичне штампе. Политичке личности креирају себе, не као одговорне представнике власти, народа, политичких организација или друштвених група, већ као ведете политичког спектакла у којем је све дозвољено, ако се пажња публике, тегобним преживљавањем изнурених грађана Србије, усмерава на политику као медијски спектакл, а не на њене суштинске садржаје и циљеве. „Спектакл је у стању да подреди себи људе, управо зато што их је економија већ потпуно подредила својим циљевима. (...) Спектакл је технолошка верзија прогона људских моћи у онострано, то је врхунац човековог одвајања од самог себе.” (Дебор 1999: 7) Сва истраживања вредносних оријентација младих у Србији, реализована у последњој деценији, показују да је највећи број усмерен на брзу и лаку зараду, забаву и хедонизам ${ }^{4}$.

Естрадна варијација доминантног културног обрасца такође је формирана под утицајем масовних медија, бројних регионалних и локалних медијских организација које се обраћају гледаоцима и слушаоцима у провинцијално-руралном социјалном миљеу, афирмишући исте културне вредности као и две претходне варијације, али прилагођавајући их свакодневном начину живота и стеченим навикама у поменутом амбијенту. И овде ,знак односи превагу у односу на оно што је њиме означено, где копија поништава оригинал, а границе између истинитог и лажног, стварности и привида једна другу искључују” (Дебор 1999: 7). Њен архетипски израз је музички фестивал у Гучи, који се пресликава на мноштво сличних лукративно мотивисаних културних манифестација у унутрашњости Србије, у којима труба и шајкача нису (више) део традиције, него роба упакована у националне стереотипе, која се продаје по законитостима понуде и

4 Види: Пројекат Свакоgневица млаgих у Србији, Институт за психологију Филозофског факултета, Београд, 2009. 
тражње који важе за сваку другу врсту робе, а некада „само” народни сабор постаје један од „брендова европске Србије”. Отуд утркивање политичара и других јавних личности да се појаве и говоре на овом „српском Вудстоку”. На маргинама оваквих културних збивања националног значаја јављају се, међутим, сваковрсне имитације у којима су јавна и приватне сфере потпуно помешане до границе апсолутног неукуса. Локалне телевизије, будући да немају новац за продукцију скупих „ријалити” формата, куповину филмова и серијала, продају време за директне преносе свадбених и других породичних свечаности неиживљених гастарбајтера, али и локалних тајкуна који освештавају новоизграђене камене темељце будућих производних хала и мегамаркета, уз обавезно „певање и пуцање”, тј. народно весеље које њихови непријављени намештеници гледају и, препознајући себе на телевизијским екранима, заборављају да већ сутра могу (п)остати само део једне имитаторске медијско-политичке кулисе. Не постоји регион у Србији у којем није, у медијском пољу, могуће препознати медијску организацију која је, емитованим програмом или објављеним текстовима у локално-регионалним новинама, промотер вредности ове варијације доминатног културног обрасца.

Насупрот доминантном културном обрасцу и његовим описаним варијацијама, тек у малим и скрајнутим друштвеним енклавама може се уочити постојање алтернативних, самим тим и маргинализованих културних образаца, као што су грађанско-традиционални, социјално-револуционарни или културни обрасци различитих поткултурних друштвених група.

\section{Ка новом културном обрасцу у Србији}

Опстајање поменутог, сва је прилика медијски наметнутог, као доминантног културног обрасца у Србији, представља најозбиљнију претњу културном идентитету српског народа и, последично, развоју српског друштва. Није, наиме, могућ друштвени развој било које социјалне заједнице без очувања и развоја културног идентитета већине њених припадника, ако у разумевању речи идентитет пођемо од њене етимолошке основе у латинском језику - истовентости са собом.

Али, у ком смеру? 
На то питање може се одговорити само осмишљеном и дугорочном Стратегијом развоја културе у Србији, која треба и мора да буде основа за рекунфигурисање медијског система и деловање масовних медија, односно медијских организација као субјеката јасно профилисане културне политике. И једно и друго треба да резултирају новим, аутентичним културним обрасцем у Србији.

„Социјална мера остварености новог културног обрасца огледала би се у развијању самосвести сваког припадника, или барем знатне већине српског народа о значају очувања традиционалних културних вредности за опстанак народа, друштва и државе, али и њиховог сталног, развојног обогаћивања културним достигнућима, саобразних новој, савременој епохи и будућности која већ увелико показује своје техницизирано лице.” (Милетић и Милетић, 2012: 62). Она би требало да се испољава кроз самосвест већине о:

- значају српског језика и ћириличног писма, митологије, православља, обичаја, традиције и већ остварених материјалних и културних достигнућа у филозофији, науци, нарочито историјској, и уметностима као најважнијим условима очувања српског националног и културног идентитета;

- постојању јединственог српског културног простора на Балкану, који, осим република бивше Југославије, обухвата и све њене некадашње суседе са значајном српском дијаспором;

- неупитности очувања територијалног интегритета и државног суверенитета Србије од Суботице до Призрена и од Крупња до Кладова;

- историјској и културној, политичкој и државној, регионалној и глобалној међусобној упућености свих српских држава на Балкану;

- позитивним и, нарочито, негативнима аспектима процеса глобализације, где се ови други испољавају у неоимперијалистичким аспирацијама према малим народима и државама у политичком концепту тзв. ограниченог суверенитета;

- потреби демистификације, на темељу већ досегнутих научних сазнања, идеологијских мантри о непостојању алтернатива за позицију Србије у матици глобалних друштвених промена и новонастајућем друштвено-историјском контексту;

- значају интелектуалног капитала као развојног ресурса долазеће економије знања и утицају образовања, науке и техничко-технолошких иновација на привредни развој и раст запошљавања; 
- неопходности заустављања негативних деомографских тенденција, стварањем материјалних услова за пораст наталитета и заустављање исељавања у неповрат младих и школованих генерација из Србије;

- потреби садржинског и формалног интеркултурног повезивања новог културног обрасца, у процесу истинске, алтернативне глобализације са изграђеним културним обрасцима других народа света, уз услов да ту повезаност треба и једино је могуће остварити посредством садржинске размене елемената традиционалних култура и нових културних идеја и тековина, научних, технолошких и уметничких достигнућа новог миленијума, које треба да постану општа, универзална баштина светске цивилизације, усвајањем принципа истинске равноправне сарадње, разумевања, размене, солидарности и поштовања националног и територијалног интегритета и суверенитета сваког народа и државе света.

Србији је данас неопходан висок степен унутрашње кохезије да би изашла из дубоке друштвене, а то увек значи културне кризе или кризе културе. Она се не може постићи без сагласности о вредностима које треба да доминирају друштвеним животом, као путоказ за социјализацију најмлађих генерација, али и аксиолошки систем унутар којег ће већина грађана организовати свој индивидуални живот, како у приватној, тако и у јавној сфери.

Мало је вероватно да може бити афирмисан без друштвеним консензусом утврђене Стратегије развоја културе у Србији и из ње изведених нормативних претпоставки функционисања медијских организација као субјеката културне политике. Јер, упркос подразумевајућој резервисаности према радикалној медијацентричности у промишљању релације масовни медији - друштво, ипак није претерано закључити да данас „све што знамо о нашем друштву, о свету у коме живимо, знамо из масовних медија” (Лухман 1996: 9). 


\section{Литература}

Бенедикт 1976: Бенедикт, Рут (1976): Обрасци кулииуре; Београд: Просвета.

Бретон 2000: Бретон, Филип (2000): Изманийулисана реч; Београд: Клио.

Голубовић 1994: Голубовић, Загорка (1994): Кулимуре у ииранзиичји

у исииочној Евройи и Јуіославији: раскорак између кулимурної и националної обрасиа, „Културе у транзицији”; Београд: Плато.

Дебор 1999: Дебор, Ги (1999): Друшииво сиекииакла; Загреб: Аркзин. Дефлер 1966: De Fleur, Melvin (1966): Theories of Mass Communication; New York: David McKay Company, Inc.

Јанићијевић 2000: Јанићијевић, Јасна (2000): Комуникаиија и кулимура;

Сремски Карловци: Издавачка књижарница Зорана Стојановића. Јанићијевић 2009: Јанићијевић, Јасна (2009): Функиије и ефекӣи масовних меgија, „Култура”, бр 120/121; Београд: Завод за проучавање културног развитка (стр. 198-213).

Лухман 1996: Luhmann, Niklas (1996): Die Realitat der Massenmedien;

Opladen: Westdeutscher Verlag

Милетић 2009: Милетић, Мирко (2009): Школа, меgији и доколища у животиу млаgих у Србији, „Обичан дан, истраживање дневне економије времена", Кулйура йолиса, посебно издање; Нови

Сад: Удружење за политичке науке Војводине (стр. 37-55).

Милетић и Милетић 2012: Милетић, Мирко и Милетић, Невена (2012):

Кулйурна йолитика у меgијском сисиему Србије, у „Култура и друштвени развој”; Београд: Мегатренд униврзитет.

Митровић 2007: Митровић, Љ. (2007): Између кулимуре зависносиии и йраїана за сойсиввеним моgелом; http://starisajt.nspm.rs/kulturnapolitika/2007_ljmitrovic.htm (приступљено 10. јула 2012.)

Томан 2001: Thoman, Elizabeth (2001): Skills \& Strategies for Media Education; Center for

Media Literacy: www. medialit.org/reading-room/skills-strategies-mediaeducation.

Закон о кулйури, „Службени гласник РС”, бр. 72/2009, Београд.

Пројекат Свакоgневица млаgих у Србији, Институт за психологију Филозофског факултета, Београд, 2009. 


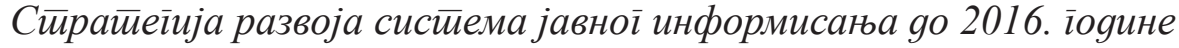
http://www.gs.gov.rs/lat/strategije-vs.html

Mirko Miletić

\section{Summary}

\section{MASS MEDIA, CULTURAL POLICY AND CULTURAL PATTERN IN CONTEMPORARY SERBIA}

The paper discusses the importance of the mass media as subjects of cultural politics in contemporary society. Starting from the empirically established fact that they are among the most important social subjects that affect the culture of each social community, the author tackles the issue of their functioning in Serbia. He points out that mass media act as agents of cultural politics outside the accepted social consensus and formally established development strategy of culture in our country. In addition to the lack of such a strategy, he noted that the mass media are not mentioned as subjects of cultural policy in the current Law on the culture and also the so-called systemic media laws ignore cultural action of media organizations. The consequence is the dominance of the cultural pattern, which is not in accordance with the socio-historical context and development goals of the Serbian society. Finally, the author sketched elements of a cultural pattern which the mass media should affirm as a condition under which Serbia should get out of the deep social crisis, which is always a cultural crisis.

Key words: mass media, cultural policy, cultural development strategy, dominant cultural pattern, new cultural pattern. 